\title{
Wymiana informacji w Unii Europejskiej w zakresie podatków bezpośrednich - stan obecny i perspektywy
}

\section{Wprowadzenie}

Wymiana informacji jest podstawową formą międzynarodowej współpracy podatkowej. Warunkuje ona nie tylko efektywność krajowych systemów podatkowych, ale stanowi niekiedy warunek konieczny stosowania określonych regulacji podatkowych. Nie byłoby możliwe wprowadzenie wspólnego systemu opodatkowania podatkiem od towarów i usług bez zapewnienia skutecznego mechanizmu przekazywania informacji i stworzenia baz danych o podmiotach i transakcjach wewnątrzwspólnotowych. Podobnie sytuacja kształtuje się w przypadku podatku akcyzowego, gdzie zabezpieczenie obrotu wyrobami akcyzowymi uzależnione jest $w$ dużej mierze od przepływu informacji o dokonywanym transporcie pomiędzy administracjami poszczególnych państw. Unormowania dotyczące wymiany informacji podatkowych wprowadzane były do systemu prawnego Unii Europejskiej jako konsekwencja, a niekiedy niezbędny element szerszego zjawiska harmonizacji podatkowej. W tym kontekście nie powinna dziwić znaczna dysproporcja unormowań odnoszących się do podatków pośrednich - objętych harmonizacją oraz bezpośrednich, które co do zasady harmonizacji nie podlegają. Proces ten znalazł swoje odzwierciedlenie w obowiązującym stanie normatywnym. O ile bowiem wymiana informacji w zakresie podatków pośrednich stała się przedmiotem unormowań zawartych w rozporządzeniach wydanych przed kilkoma laty ${ }^{1}$,

* Dr hab. Dominik Mączyński - Katedra Prawa Finansowego, Wydział Prawa i Administracji, Uniwersytet im. Adama Mickiewicza w Poznaniu.

${ }^{1}$ Rozporządzenie Rady (WE) nr 1798/2003 z dnia 7 października 2003 r. w sprawie współpracy administracyjnej w dziedzinie podatku od wartości dodanej i uchylające rozporządzenie (EWG) nr 218/92, Dz. U. L z 2003 r. Nr 264 ze zm. (s. 1); rozporządzenie Komisji (WE) nr 1925/2004 z dnia 29 października 2004 r. ustanawiające szczegółowe zasady wykonywania niektórych przepisów rozporządzenia Rady (WE) nr 1798/2003 w sprawie współpracy administracyjnej w dziedzinie podatku od wartości dodanej, Dz. U. L z 2004 r. Nr 331 (s. 13); rozporządzenie Rady (WE) nr 2073/2004 z dnia 16 listopada 2004 r. w sprawie współpracy administracyjnej w dziedzinie podatków akcyzowych, Dz. U. L z 2004 r. Nr 359 (s. 1). 
o tyle zasady dotyczące wymiany informacji w zakresie podatków bezpośrednich wciąż wynikają z dyrektywy wydanej jeszcze w latach $70 .^{2}$

Pomijając sytuacje podlegające szczególnym uregulowaniom³, obecnie państwa członkowskie UE mogą wymieniać informacje odnoszące się do podatków bezpośrednich w oparciu o trzy różnorodne grupy podstaw prawnych. Po pierwsze, wymiana informacji podatkowych może następować na podstawie bilateralnych umów o unikaniu podwójnego opodatkowania, zawieranych pomiędzy państwami członkowskimi Unii Europejskiej. Po drugie, podstawę prawną współpracy może stanowić Konwencja o wzajemnej pomocy administracyjnej w sprawach podatkowych (dalej: Konwencja) ${ }^{4}$. Po trzecie, podstawę prawną wymiany informacji podatkowych stanowić mogą obowiązujące przepisy poszczególnych państw członkowskich Unii Europejskiej wprowadzone do systemów podatkowych jako wynik implementacji dyrektywy Rady dotyczącej wzajemnej pomocy właściwych władz państw członkowskich w dziedzinie podatków bezpośrednich, niektórych podatków akcyzowych oraz opodatkowania składek ubezpieczeniowych (dalej: dyrektywa 77/799).

\section{Wymiana informacji podatkowych w podatkach bezpośrednich w świetle umów zawieranych pomiędzy państwami czlonkowskimi Unii Europejskiej}

Bilateralne umowy międzynarodowe stanowią uniwersalną podstawę prawną wymiany informacji podatkowych pomiędzy państwami je zawierającymi, także w sytuacji, gdy państwa-strony umowy są jednocześnie państwami członkowskimi UE. Polska zawarła bilateralne umowy podatkowe ze wszystkimi państwami członkowskimi UE i te umowy zawierają postanowienia dotyczące wymiany informacji podatkowych. $Z$ uwagi na to, że treść zawieranych umów jest oparta na Modelu Konwencji OECD, zakres unormowań przyjęty w tych umowach jest zbliżony. Większość obowiązujących umów bilateralnych oparła zasady wymiany informacji na przepisach Modelu Konwencji OECD w brzmieniu sprzed 2005 r., co w szczególności oznacza, że umowy te nie stwarzają podstaw do domagania się informacji objętych tajemnicą bankową. Wyjątkiem są tu umowy zawarte

${ }^{2}$ Dyrektywa Rady 77/799/EWG z dnia 19 grudnia 1977 r., dotycząca wzajemnej pomocy właściwych władz Państw Członkowskich w dziedzinie podatków bezpośrednich, niektórych podatków akcyzowych oraz opodatkowania składek ubezpieczeniowych, Dz. U. L 336, s. 015-020.

${ }^{3}$ Por. m.in. dyrektywa Rady 2003/48/WE z dnia 3 czerwca 2003 r. w sprawie opodatkowania dochodów z oszczędności w formie wypłacanych odsetek, Dz. U. L 157, s. $38-48$ (polskie wydanie specjalne, Rozdział 9, Tom 1, s. 369-379).

${ }^{4}$ Konwencja o wzajemnej pomocy administracyjnej $\mathrm{w}$ sprawach podatkowych $\mathrm{z}$ dnia 25 stycznia 1988 r., ratyfikowana przez Polskę w dniu 19 maja 1997 r., Dz. U. z 1998 r. Nr 141, poz. 913 i 914. 
ze Szwecją oraz Wielką Brytanią i Irlandią Północną, które przewidują, że państwo nie może się powołać na tzw. tajemnicę bankową przy odmowie udzielenia informacji podatkowych, co oznacza, że nie można odmówić dostarczenia informacji wyłącznie $\mathrm{z}$ takiego powodu, że informacja jest w posiadaniu banku, innej instytucji finansowej, przedstawiciela, agenta lub powiernika albo dotyczy interesów właścicielskich danej osoby ${ }^{5}$. Należy jednak pamiętać, że umowy międzynarodowe wyznaczają jedynie minimalne standardy postępowań państw członkowskich, państwa moga jednak dokonywać wymiany w szerszym zakresie ${ }^{6}$. Zgodnie $\mathrm{z}$ postanowieniami zawartymi w obowiązujących obecnie umowach międzynarodowych, właściwe organy umawiających się państw wymieniają informacje, które są niezbędne do stosowania postanowień umowy oraz ustawodawstwa wewnętrznego umawiających się państw, w odniesieniu do podatków objętych zawartą umową, w zakresie, w jakim opodatkowanie w tym ustawodawstwie nie jest z nią sprzeczne ${ }^{7}$. Wymiana informacji nie jest ograniczona zakresem podmiotowym umowy, co oznacza, że państwa mogą udostępniać informacje dotyczące wszystkich osób, wobec których posiadają dane, a nie tylko wobec rezydentów czy obywateli.

Konwencja o wzajemnej pomocy administracyjnej w sprawach podatkowych jest umową wielostronną. Wśród państw-stron Konwencji znajduje się obecnie 13 państw Unii Europejskiej ${ }^{8}$. Zgodnie z art. 4 ust. 1 Konwencji przedmiotem wymiany mogą być wyłącznie te informacje, które mają związek z wymiarem i poborem podatków, ściganiem i egzekucją roszczeń podatkowych oraz postępowaniem karnym przed organem administracyjnym lub wszczęciem postępowania karnego przed organem orzekającym. Konwencja normuje trzy podstawowe formy wymiany informacji podatkowych: wymianę informacji na żądanie, automatyczną wymianę informacji oraz spontaniczną wymianę informacji. W zakresie pojęcia wymiany informacji mieszczą się także inne formy współpracy, tj. jednoczesne kontrole podatkowe i kontrole podatkowe za granicą. Wymiana informacji na żądanie została uregulowana na gruncie Konwencji w sposób ogólnikowy i polega na przekazaniu państwu wnioskującemu wszelkich informacji mających związek z celami podatkowymi, dotyczących konkretnych osób lub transakcji, na żądanie państwa wnioskującego. Automatyczna wymiana informacji polega na cyklicznym przesyłaniu informacji podatkowych przez administrację jednego państwa

5 Por. art. 25 ust. 5 umowy ze Szwecją i art. 26 ust. 5 umowy z Wielką Brytanią i Irlandią Północną.

6 J. Banach, Wymiana informacji podatkowych pomiędzy administracjami skarbowymi państw-stron umów o unikaniu podwójnego opodatkowania, „Biuletyn Skarbowy” 1999, nr 1, s. 1.

${ }^{7} \mathrm{Na}$ ten temat: J. Banach, Polskie umowy o unikaniu podwójnego opodatkowania. Komentarz, Warszawa 2002, s. 404 i n.

8 Belgia, Dania, Finlandia, Francja, Hiszpania, Holandia, Irlandia, Polska, Portugalia, Słowenia, Szwecja, Wielka Brytania, Włochy. 
właściwemu organowi innego państwa ${ }^{9}$. Dokonuje się to w sposób zautomatyzowany w odniesieniu do określonych rodzajów uzyskanych na terenie danego państwa dochodów lub pobranych $\mathrm{w}$ tym państwie podatków ${ }^{10}$. Metoda ta wymaga spełnienia dwóch warunków. Po pierwsze, administracje poszczególnych państw muszą szczegółowo określić zakres informacji będących przedmiotem wymia$n^{11}$. Po drugie, automatyczna wymiana informacji wymaga wykorzystywania systemów informatycznych umożliwiających sprawne przekazywanie informacji. Przepisy Konwencji nie przesądzają ani zakresu przedmiotowego, ani procedury, w jakiej ma następować automatyczna wymiana informacji. Kwestia ta została pozostawiona do dwustronnych uzgodnień pomiędzy poszczególnymi państwami. W praktyce Konwencja nie nakłada na umawiające się państwa obowiązku podjęcia takiej współpracy. Spontaniczna wymiana informacji polega na przekazywaniu informacji bez wcześniejszego wniosku ze strony drugiego państwa w przypadkach określonych w Konwencji ${ }^{12}$. Zgodnie z art. 7 Konwencji państwo przekazuje informacje podatkowe, jeżeli ma podstawy do przypuszczeń, że w innym państwie może mieć miejsce utrata podatków, podatnik korzysta z przywileju podatkowego, który może skutkować powstaniem lub podniesieniem wysokości zobowiązania podatkowego $\mathrm{w}$ innym państwie, transakcje handlowe prowadzone są na terenie co najmniej dwóch państw w taki sposób, że może to skutkować uszczupleniem wpływów podatkowych, są podstawy do przypuszczeń, że zaniżenie podatków może powstać w wyniku fikcyjnego transferu zysków w ramach grup przedsiębiorstw lub przekazane informacje mogą mieć znaczenie dla ustalenia zobowiązania podatkowego na terenie innego państwa.

\section{Wymiana informacji podatkowych na podstawie dyrektywy $77 / 799$}

Wśród form współpracy pomiędzy właściwymi organami poszczególnych państw członkowskich Unii Europejskiej normowanych w dyrektywie 77/799 znajdują się: wymiana informacji na wniosek (art. 2), regularna (automatyczna) wymiana informacji (art. 3), wymiana informacji z urzędu (spontaniczna wymia-

9 A. Bavila, Some issues on the exchange of information between revenue authorities, „Dritto e Practica Tributaria Internazionale" 2001, vol. 1, nr 2, s. 284 i n.

${ }^{10} \mathrm{~K}$. Bany, Międzynarodowa wspótpraca w sprawach podatkowych. Konwencja o wzajemnej pomocy administracyjnej w sprawach podatkowych państw członkowskich Rady Europy i OECD, Warszawa 1999, s. 17.

${ }^{11}$ D. E. Spencer, Mutual Assistance Convention Has Its Limitation, „The Journal of International Taxation" 1991, nr 1/2, s. 286.

${ }_{12}$ M. Penney, Implications of the Council of Europe and OECD Convention on Mutual Administrative Assistance in Tax Matters, „Tax Planning International” 1988, vol. 15, nr 6, s. 4; A. Bavila, Some issues on the exchange of information..., s. $278 \mathrm{i} \mathrm{n.}$ 
na informacji - art. 4), obecność przedstawicieli organów administracji jednego państwa w siedzibie władz innego państwa (art. 6), notyfikacja (powiadomienie art. 8a) i równoczesne kontrole (art. 8b). Wąsko rozumiana wymiana informacji podatkowych ogranicza się jednak do trzech podstawowych form: wymiany informacji na wniosek, regularnej (automatycznej) wymiany informacji oraz wymiany informacji z urzędu.

Warunkiem złożenia wniosku o udzielenie informacji podatkowej jest wyczerpanie przez organ państwa proszącego o udzielenie pomocy własnych zwyczajowo uznanych źródeł informacji, które mógłby użyć, odpowiednio do okoliczności, w celu uzyskania wymaganych informacji, bez ryzyka uzyskania poszukiwanych informacji, po zakończeniu postępowania. Warunek ten nie stanowi jednak bezwzględnej przesłanki uniemożliwiającej podjęcie efektywnej współpracy. Organ państwa członkowskiego może bowiem przekazać żądaną informację nawet wówczas, gdy organ państwa proszącego tego warunku nie spełnił. Jeżeli organ państwa, do którego skierowano wniosek o udzielenie pomocy, uzna go za zasadny, ma obowiązek przekazania informacji także wtedy, gdy nie posiada danych wskazanych we wniosku drugiego państwa. W takiej sytuacji w celu udzielenia żądanych informacji właściwy organ, który jest adresatem wniosku, jest zobowiązany przeprowadzić w danej sprawie niezbędne postępowanie. Postępowanie to prowadzone jest tak, jakby organ ten działał na swój własny rachunek lub na żądanie innego organu tego samego państwa.

Zakres i zasady podejmowania współpracy polegającej na regularnej wymianie informacji nie zostały sprecyzowane na gruncie dyrektywy 77/799. Zgodnie art. 3 tej dyrektywy państwa podejmą regularną wymianę informacji jedynie w odniesieniu do rodzajów spraw, które określą w ramach procedury konsultacyjnej, ustanowionej w art. 9 dyrektywy. Istotą tej formy współpracy jest przekazywanie informacji podatkowych właściwym organom innych państw bez uprzedniego wniosku o ich przekazanie ${ }^{13}$. Forma ta wymaga szczegółowych ustaleń pomiędzy poszczególnymi państwami zamierzającymi podjąć współpracę zarówno co do zakresu przekazywanych informacji, jak i sposobu ich wymiany.

Znacznie szerzej dyrektywa 77/799 normuje wymianę informacji z urzędu (spontaniczną wymianę informacji). Spontaniczna wymiana informacji nie oznacza jednak wymiany „dobrowolnej”, gdyż przesłanki jej dokonania zostały precyzyjnie ustalone ${ }^{14}$. Podobnie jak w przypadku regularnej wymiany informacji, dane przekazywane są bez konieczności uprzedniego złożenia wniosku przez właściwy organ zainteresowanego państwa. W odróżnieniu jednak od poprzednio omówionej formy wymiany informacji, przesłanki przekazania informacji z urzędu zostały enumeratywnie wskazane w dyrektywie. Właściwy organ nie ma też obowiązku przeprowadzać odrębnego postępowania mającego na celu uzyskanie

${ }_{13}$ B. J. M. Terra, P. J. Wattel, European Tax Law, Warszawa 2008, s. 669-670.

${ }^{14}$ Ibidem, s. 670. 
informacji mających być przedmiotem wymiany. Właściwy organ państwa członkowskiego udziela znanych mu informacji bez uprzedniego wniosku organu innego zainteresowanego państwa członkowskiego, jeżeli:

- właściwy organ jednego państwa członkowskiego ma podstawy przypuszczać, że może dojść do zmniejszenia podatku w drugim państwie członkowskim;

- podatnik uzyskuje obniżkę lub zwolnienie z podatku w jednym państwie członkowskim, co może być powodem do podwyższenia podatku lub powstania obowiązku podatkowego w innym państwie członkowskim;

- w kontaktach gospodarczych między podatnikiem jednego państwa członkowskiego a podatnikiem innego państwa członkowskiego, które będą prowadzone w jednym lub więcej niż jednym kraju w taki sposób, powstanie sytuacja, która może doprowadzić do oszczędności podatkowej w jednym z obydwu lub w obydwu państwach członkowskich;

- właściwy organ państwa członkowskiego ma podstawy przypuszczać, że możliwa jest oszczędność podatkowa przez fikcyjny transfer zysków wewnątrz grupy przedsiębiorstw;

- w jednym państwie członkowskim, w związku z informacjami, które zostały przekazane przez właściwy organ innego państwa członkowskiego, został ustalony stan faktyczny, który może być przydatny do naliczenia podatku w tym innym państwie członkowskim.

Przepisy dyrektywy 77/799 zostały implementowane do polskiego porządku prawnego w przepisach art. 305a-305m o.p..$^{15} \mathrm{O}$ ile jednak przepisy o.p. precyzyjnie normują zasady przekazywania informacji podatkowych na wniosek oraz spontanicznej wymiany informacji podatkowych, o tyle w zakresie automatycznej wymiany informacji podatkowych o.p. nie formułuje norm nakazujących podjęcie takiej współpracy, a jedynie stwarza uprawnienie po stronie ministra finansów do zawierania porozumień międzyresortowych, które będą zawierać regulacje odnoszące się do tej formy współpracy. W praktyce oznacza to konieczność wyrażenia woli podjęcia współpracy przez co najmniej dwa państwa członkowskie UE i określenia, w jakim zakresie i na jakich zasadach współpraca ta będzie przebiegać.

\section{Zasady wymiany informacji podatkowych w świetle dyrektywy 2011/16}

Istotne zmiany $\mathrm{w}$ zakresie wymiany informacji podatkowych dotyczących podatków bezpośrednich nastąpią z początkiem roku 2013 i 2014. Wynika to z faktu, że państwa członkowskie UE zobowiązane są do wprowadzenia w życie

${ }_{15}$ Ustawa z dnia 29 sierpnia 1997 r. Ordynacja podatkowa, t.j. Dz. U. z 2005 r. Nr 8, poz. 60 ze zm. (dalej: o.p.). 
przepisów niezbędnych do wykonania dyrektywy Rady 2011/16/UE w sprawie współpracy administracyjnej w dziedzinie opodatkowania i uchylającej dyrektywę 77/799/EWG (dalej: dyrektywa 2011/16) ${ }^{16}$ z dniem 1 stycznia 2013 r., natomiast współpraca na podstawie tych przepisów winna zostać podjęta $\mathrm{z}$ dniem 1 stycznia $2014 \mathrm{r}$.

W porównaniu z unormowaniami obowiązującymi na mocy dyrektywy 77/799 modyfikacji uległy formy wymiany informacji. Dyrektywa 2011/16 normuje bowiem wymianę informacji na wniosek, obowiązkową automatyczną wymianę informacji oraz spontaniczną wymianę informacji. Nowością, wprowadzającą zasadniczą reformę w zakresie wymiany informacji podatkowych, jest przede wszystkim wprowadzenie obowiązku podjęcia automatycznej wymiany informacji. Wymianie podlegają informacje, które - jak stanowi art. 1 ust. 1 dyrektywy 2011/16 - wydają się istotne do celów stosowania i egzekwowania krajowych przepisów państw członkowskich dotyczących podatków. Co do zasady, wymiana informacji dotyczy wszelkich podatków, w tym podatków lokalnych, z wyjątkiem podatku od wartości dodanej, podatku akcyzowego oraz cła.

Wymiana informacji na wniosek oznacza wymianę informacji na podstawie wniosku kierowanego w konkretnym przypadku przez wnioskujące państwo członkowskie do współpracującego państwa członkowskiego. Państwo proszone o udzielenie informacji jest zobowiązane do przekazania informacji znajdujących się w jego posiadaniu lub uzyskanych przez nie w wyniku postępowania administracyjnego. Organ państwa proszonego o udzielenie informacji zobowiązany jest do podjęcia wszelkich niezbędnych czynności w celu uzyskania informacji. Informacja winna być udzielona najszybciej jak to możliwe, lecz nie później niż 6 miesięcy od daty otrzymania wniosku. Jednak w przypadku, gdy organ współpracujący posiada już żądane informacje, są one przekazywane w ciągu 2 miesięcy od tej daty.

Wymiana automatyczna oznacza systematyczne przekazywanie określonych z góry informacji innemu państwu członkowskiemu, bez uprzedniego wniosku, w ustalonych z góry, regularnych odstępach czasu. W kontekście art. 8 dostępne informacje odnoszą się do informacji zawartych w dokumentacji podatkowej państwa członkowskiego przekazującego informacje, które uzyskuje się zgodnie z procedurami gromadzenia i przetwarzania informacji w tym państwie członkowskim. Od 1 stycznia 2014 r. właściwy organ każdego państwa członkowskiego UE jest zobowiązany do przekazania za okresy rozliczeniowe informacji, którymi dysponuje w odniesieniu do osób zamieszkałych w innym państwie członkowskim, dotyczących poszczególnych kategorii dochodu i kapitału, zgodnie z ich interpretacją na mocy krajowych przepisów państwa członkowskiego przekazującego. Udostępniane dane mają obejmować: dochody z zatrudnienia, wynagrodzenia

${ }^{16}$ Dyrektywa Rady 2011/16/UE z dnia 15 lutego 2011 r. w sprawie współpracy administracyjnej w dziedzinie opodatkowania i uchylająca dyrektywę 77/799/EWG, Dz. U. UE L 64, s. 1. 
dyrektorów, produkty ubezpieczenia na życie nieobjęte innymi unijnymi aktami prawnymi dotyczącymi wymiany informacji i innych podobnych środków, świadczenia emerytalne i rentowe, własność nieruchomości i dochody z tego tytułu. Informacje winny być przekazywane co najmniej raz w roku, w ciągu 6 miesięcy od zakończenia w państwie członkowskim roku podatkowego, w którym informacje stały się dostępne.

Wymiana spontaniczna oznacza nieregularne przekazywanie informacji innemu państwu członkowskiemu, w dowolnym momencie i bez uprzedniego wniosku. Wymiana spontaniczna również ma charakter obligatoryjny, winna być podjęta, gdy:

- właściwy organ jednego państwa członkowskiego ma podstawy przypuszczać, że może dojść do strat podatkowych w innym państwie członkowskim;

- osoba podlegająca obowiązkowi podatkowemu uzyskuje obniżkę podatku lub zwolnienie $\mathrm{z}$ podatku $\mathrm{w}$ jednym państwie członkowskim, co byłoby podstawą do podwyższenia podatku lub powstania obowiązku podatkowego w innym państwie członkowskim;

- kontakty gospodarcze między osobą podlegającą obowiązkowi podatkowemu w jednym państwie członkowskim a osobą podlegającą obowiązkowi podatkowemu w innym państwie członkowskim są prowadzone w co najmniej jednym kraju w taki sposób, że może to doprowadzić do oszczędności podatkowych $\mathrm{w}$ jednym z tych państw członkowskich lub w drugim lub w obydwu z nich;

- właściwy organ państwa członkowskiego ma podstawy przypuszczać, że oszczędność podatkowa może wynikać z fikcyjnych transferów zysków wewnątrz grupy przedsiębiorstw;

- informacje przekazane jednemu państwu członkowskiemu przez właściwy organ innego państwa członkowskiego umożliwiły uzyskanie informacji, które mogą być istotne do określenia obowiązku podatkowego w tym drugim państwie członkowskim.

Ponadto właściwe organy każdego z państw członkowskich mogą przekazywać w ramach spontanicznej wymiany wszelkie dostępne informacje, które mogą być przydatne właściwym organom pozostałych państw członkowskich. Informacje winny być przekazane najszybciej jak to możliwe, lecz nie później niż w terminie jednego miesiąca od momentu uzyskania dostępu do tych informacji.

\section{Podsumowanie}

Wejście w życie dyrektywy 2011/16 w istotny sposób zmienia zasady wymiany informacji podatkowych w Unii Europejskiej w zakresie podatków bezpośrednich. Przede wszystkim zwraca uwagę doprecyzowanie sposobu wymiany informacji podatkowych, przejawiające się w szczególności w dokładnym wskazaniu rodzaju udostępnianych informacji oraz terminów na ich przekazanie. Wydaje się 
jednak, iż wydanie dyrektywy 2011/16 ukazuje zwłaszcza zmianę w sposobie postrzegania roli, jaką przypisuje się wymianie informacji podatkowych. Dotąd wymiana informacji podatkowych stanowiła konsekwencję i uzupełnienie harmonizacji legislacji podatkowej w Unii Europejskiej. W przypadku podatków pośrednich - podatku od wartości dodanej oraz podatku akcyzowego - wymiana informacji normowana była w zakresie niezbędnym dla stworzenia wspólnego systemu opodatkowania tymi podatkami i pełniła rolę służebną wobec ich harmonizacji. Uwagi te zasadniczo odnoszą się do automatycznej wymiany informacji, bez której nie sposób wyobrazić sobie stosowania przepisów dotyczących opodatkowania pośredniego na terenie Unii Europejskiej. Automatyczna wymiana informacji zastąpiła $\mathrm{w}$ istocie granice fiskalne $\mathrm{i}$ okazała się niezbędna dla urzeczywistnienia idei wspólnego rynku w ramach Unii Europejskiej.

Dyrektywa 2011/16 zasadniczo zmienia dotychczasową praktykę legislacyjną. Podkreślenia wymaga, że wymiana informacji normowana na gruncie dyrektywy 2011/16 odnosi się do podatków, które co do zasady nie podlegają harmonizacji w ramach prawodawstwa unijnego. Nakładając na państwa członkowskie obowiązek podjęcia automatycznej wymiany informacji podatkowych, regulacje dyrektywy 2011/16 wyraźnie wykraczają poza funkcję wspierającą procesy harmonizacyjne. Automatyczna wymiana informacji stała się celem samym w sobie i mimo braku kompleksowej harmonizacji podatków bezpośrednich z pewnością przyczyni się do ograniczenia konkurencji podatkowej między państwami członkowskimi UE oraz zwiększenia efektywności systemów podatkowych. Istota dyrektywy 2011/16 sprowadza się bowiem do przekazania zainteresowanemu państwu wszelkich informacji istotnych dla wymiaru i poboru podatku.

Dyrektywa 2011/16 została sformułowana w sposób umożliwiający jej możliwe szerokie zastosowanie i maksymalną skuteczność. Zgodnie z art. 1 ust. 1 dyrektywy 2011/16 przedmiotem wymiany są informacje, które ,wydają się istotne" do celów stosowania i egzekwowania krajowych przepisów. Tego rodzaju przepis nakazuje państwom członkowskim wymianę informacji także pośrednio związanych z określeniem obowiązku podatkowego, odnoszących się przykładowo do sytuacji osobistej podatnika, a nie jedynie wielkości osiągniętego dochodu. W przypadku wymiany dokonywanej na wniosek, właściwy organ państwa członkowskiego proszonego o przekazanie informacji jest zobowiązany do udostępnienia nie tylko informacji znajdujących się w jego posiadaniu, lecz także uzyskanych przez niego w wyniku postępowania administracyjnego, co oznacza konieczność przeprowadzenia wszelkiego rodzaju kontroli, postępowań wyjaśniających oraz innych działań w celu zapewnienia właściwego stosowania przepisów podatkowych. W odniesieniu do wszystkich form wymiany informacji unormowanych na mocy dyrektywy 2011/16, ramy postępowania ograniczone zostały bardzo restrykcyjnie zakreślonymi terminami.

Przedstawione powyżej unormowania prowadzą do zasadniczych zmian w systemie wymiany informacji w zakresie podatków bezpośrednich, co nie po- 
zostanie bez wpływu na treść krajowych unormowań prawnych. Nowelizacji wymagać będą przepisy o.p., w szczególności w zakresie uregulowania automatycznej wymiany informacji. Dotychczas przepisy o.p. uprawniały jedynie ministra finansów do zawierania porozumień międzyresortowych, a podjęcie współpracy miało charakter fakultatywny. $\mathrm{W}$ treści zawartego porozumienia strony mogły w zasadzie dowolnie kształtować zakres i zasady współpracy. Obecnie automatyczna wymiana informacji podatkowych wymagać będzie precyzyjnego ujęcia w przepisach o.p. i przybierze charakter współpracy obligatoryjnej. To z pewnością zasadnicza zmiana nie tylko dla krajowej administracji podatkowej, lecz także dla podatników uzyskujących dochody lub posiadających majątek na terenie więcej niż jednego państwa Unii Europejskiej. Podatnicy muszą być świadomi, że właściwy organ podatkowy będzie dysponował pełniejszą niż do tej pory wiedzą o okolicznościach mających wpływ na wielkość obciążeń podatkowych. 